\title{
Review
}

\section{Salmonellosis: A food borne zoonotic and public health disease in Egypt}

\author{
Wafaa A Abd El-Ghany ${ }^{1}$ \\ ${ }_{1}$ Poultry Diseases Department, Faculty of Veterinary Medicine, Cairo University, Egypt
}

\begin{abstract}
Salmonellosis is an important food borne disease of public health significance. Global estimates of the disease burden shows more than 20 million cases and 0.15 million deaths annually. The disease caused by a variety of Salmonella organisms worldwide. Salmonella pathogens are belonging to family Enterobacteriaceae that are known to infect many hosts inducing variable clinical diseases pictures. Typhoidal and nontyphoidal Salmonellae are common diseases among Egyptians with severe socioeconomic losses. Different species of animals and poultry as well as their products are the main sources and reservoirs for zoonotic human illness. Enteric fever and gastroenteritis are the main clinical manifestations in patients. Great attention toward salmonellosis drug resistance, prevention and control should be considered.
\end{abstract}

Key words: Animals; Egypt; human; poultry; public health; Salmonella spp.

J Infect Dev Ctries 2020; 14(7):674-678. doi:10.3855/jidc.12739

(Received 30 March 2020 - Accepted 09 July 2020)

Copyright (C) 2020 Abd El-Ghany. This is an open-access article distributed under the Creative Commons Attribution License, which permits unrestricted use, distribution, and reproduction in any medium, provided the original work is properly cited.

\section{Introduction}

Salmonellosis is considered as one of the most important life threating bacterial zoonotic disease of human as well as animals and poultry species. There are more than 2500 serovars of Salmonella worldwide. In humans, Salmonella enterica Typhi (S. Typhi) and Salmonella enterica Paratyphi (S. Paratyphi) cause typhoid fever and paratyphoid fever, respectively [1], while salmonellosis is an overarching term which includes invasive infection with all serovars of salmonella, as well as the normally gut restricted infections of food poisoning. [2]. Non-typhoidal salmonellosis is caused by several other Salmonella serovars rather than serovars Typhi and Paratyphi [3]. Animals and poultry are commonly infected with $S$. Enteritidis and $S$. Typhimurium that can be transmitted to human [4]. Animal products including; poultry meat, eggs and milk, water, domestic and wild animals, rodents and pets have been implicated as important sources for human salmonellosis outbreaks [5]. It has been found that poultry sectors alone can account for up to $50 \%$ of salmonellosis outbreaks [6,7]. Although human infection with Salmonella serovars occurs worldwide, the actual burden is poorly understood in most countries where the disease is endemic. Salmonella's infections are endemic in some developing countries, including Egypt and represent a serious public health hazard [8]. Egypt is at a crossroads that connects Africa, Asia and Europe. Egypt is located in the North-Eastern part of Africa continent and has 27 governorates with about 100 million inhabitants. Numerous zoonotic diseases are of importance in Egypt; one of them is Salmonella infection. Accordingly, in this review article, we will focus on the incidence of Salmonellae infections among Egyptians, sources and reservoirs of infection, the clinical picture of the disease, drug resistance and the possible prevention and control regimen.

\section{Incidence among Egyptians}

The high incidence of salmonellosis in Egypt may be related to scarce information on the disease significance and distribution, behavioral, environmental and socioeconomic factors as well as the lack of information about the possible means of transmission and the suitable control measures. The first recorded cases of typhoid fever among Egyptians was early in 1901 [9]. The Egyptian Ministry of Health and Population, the U.S. Naval Medical Research Unit3 and the Centers for Disease Control and Prevention in 2001 made a piolet study to measure the incidence of typhoid fever in Lower Egypt and the results estimated 13 cases /100,000 persons per year [10]. Reported in 2006 a study conducted in Fayoum governorate estimated the incidence of typhoid fever to be 59/100,000 persons/year and the highest incidence occurred among school-aged children [11]. Out of 128 consecutive children and adult patients in Benha Fever 
Hospital, 34 were infected with typhoid fever [12]. The incidence of $S$. Typhi infection increased among patients with chronic hepatitis C virus $[13,14]$. Moreover, non-typhoidal Salmonellae were identified as 22 isolates out of 500 stool samples of cases with gastroenteritis in El-Menya governorate [15].

\section{Sources and reservoirs of infection}

Live chickens as well as chicken products are incriminated as major sources of human food borne salmonellosis [16]. In broiler chicken farms of Egypt, El-Shaboury and Basha [17] identified 5 Salmonella strains as $S$. Typhimurium in Alexandria, while Mohamed et al. [18] serotyped isolates as $S$. Enteritidis and $S$. Typhimurium in Assiut governorates. Another trial was carried out to investigate the zoonotic potential of Salmonellae and the role of live chicken and frozen chicken meat as sources in the epidemiology of the human food borne gastroenteritis [19]. Polymerase chain reaction was used for detection of the similarity between different Salmonellae serovars from different sources and the results yielded similar amplified DNA bands in $S$. Enteritidis and $S$. Typhimurium of the same chickens and human origin. Similarly, $S$. Enteritidis was identified from chicken's meat and patient with food poisoning signs in Dakhlia governorate [20]. Later on, Salmonellae infections were isolated from broiler flocks in Eastern Egypt [21] as well as from Northern Egypt [22]. Recently in 2019, different serovars of Salmonella ( $S$. Typhimurium, $S$. Enteritidis, $S$. Anatum, $S$. Heidelberg, $S$. Muenster and $S$. Kentucky) were found in chicken's meat products that sold in local supermarkets [23]. From different poultry species, $S$. Enterica was isolated and characterized from pigeons [24] as well as from ducklings in Cairo [25]. Poultry products also are considered as the most important sources of Salmonellae transmission to human [26]. Abdel-Aziz [27] molecularly detected Salmonella serovars in chicken carcasses in South Egypt region using genus specific primers for the invA gene. A recent study carried on 420 samples representing cloacal swabs broiler chickens, environmental farm samples and freshly dressed chicken carcasses. The results revealed that 120 samples were Salmonellae positive where $S$. Enteritidis was the most predominant serotype [28]. It was detected that cross-contamination with droppings, instruments and workers hands occurred during slaughtering, de-feathering and scalding; this led to heavy contamination of chicken meat with Salmonellae [29]. Eggshell contamination among Egyptian layers flocks plays an important role in disease transmission to human [30,31]. Considering the role of milk, dairy handlers and dairy products in transmission of Salmonellae to human, 2 out of 40 faecal samples from apparently healthy dairy handlers were found positive [32]. Furthermore, it was found that $S$. Enterica was present in food samples taken from butchers, street venders, slaughterhouses and retail markets [33,34]. Regarding isolation of Salmonella from seafood products, it was found in $9.8 \%$ of 225 seafood samples collected from Alexandria province markets [35]. Moreover, diarrheic calves and camels were also regarded as additional sources of different species of Salmonellae [36,37]. Transmission from human to human was reported through faecal-oral route [38].

\section{The clinical picture}

Different Salmonellae serovars have been incriminated as a major and serious food borne zoonosis of public health significance. Outbreak and sporadic cases of typhoid fever in human ae common all over the world [39-42]. Typhoid fever is usually manifested by gastrointestinal symptoms, but some cases may show various clinical syndromes like disseminated intravascular coagulation and acute respiratory distress syndrome [43]. The clinical disease usually appears after 12-72 hours of infection and is characterized by diarrhea with fever, nausea, vomiting, abdominal pain, headache, bradycardia, and cough $[44,45]$. Without antibiotic treatment, the illness usually lasts $4-7$ days before complete recovery. In older, very young or immuno-suppressed patients the severity of the disease increases and the diarrhea can be severe requiring hospitalization. In such patients, infection may spread and invade the hepatobiliary system causing death especially without antibiotic treatments [1]. Complicated cases show liver cirrhosis, renal failure, acute pancreatitis, malignancies as well as liver abscess [46-48].

\section{Drug resistance}

Due to the extensive hazards of using different antibiotics, especially in zoonotic infections, the presence of bacterial resistance in strains infecting humans has become very common. Transmission between animals to human occurs through direct contact of people with animals, through the environment or the consumption by humans of meat, eggs or products containing eggs or meat, and [16]. The emergence of cephalosporin resistant Salmonella in Egypt has been reported [49]. The widespread prevalence of multidrug-resistant (MDR) isolates has been recorded and, for example this has influenced the 
impact of typhoid fever in developing countries [50,51]. In $S$. Enterica AMR genes were detected in $68 \%$ of isolates from meat and dairy products [34]. Moreover, AMR genes of $S$. Typhimurium from Egyptian chicken meat and humans was also recorded against chloramphenicol, streptomycin, gentamicin, trimethoprim-sulfamethoxazole, ampicillin and tetracycline [52]. Lately in 2019, Elkenany et al. [28] demonstrated AMR genes in $76.7 \%$ of $S$. Enterica strains isolated from broiler chicken farms and chicken carcasses in retail shops at El-Sharkia province. In a study carried out in Lower Egypt, AMR genes of Salmonella Typhi isolated from 29\% patients showed resistance to chloramphenicol, ampicillin and trimethoprim-sulfamethoxazole [11]. Multiple quinolones resistance was reported in diarrheic Egyptian patients with Salmonella typhoid infection $[53,54]$. High percentages of patients with non-typhoid Salmonella isolates were resistant to ampicillin, tetracycline, trimethoprim-sulphamethoxazole and chloramphenicol [15]. Similarly, high prevalence of AMR genes of non-typhoid Salmonella isolates to tetracycline and chloramphenicol was also detected [55]. A total of 76 non-typhoid Salmonellae were isolated from human and poultry in Egypt and Algeria and the isolates showed high incidence of cephalosporin's resistance [56]. A recent work of Eissa et al. [12] demonstrated that patients with typhoid fever showed resistance to combined treatment with ciprofloxacin and Cefotax.

\section{Prevention and control}

To reduce the risk of salmonellosis, it is very important to improve the biosecurity and management practices in animal and poultry flocks. Trials for protection of poultry flocks against different species of Salmonella infections using locally prepared autogenous bacterins were done with successful and promising results [57-60]. Intervention strategies including Salmonellae monitoring programs along the farm-to-table continuum should be planned [61].

Lohiniva et al. [62] advocated frequent, thorough and proper hands and body washing as well as improving the water supply and sanitary conditions. It is very crucial to regulate application of antimicrobials in Egyptian Veterinary field and study the antibiotic sensitivity profile to reduce the problem of MDR Salmonella and consequently alleviate the serious public health hazard [55]. Symptomatic treatment of especially in very young and the elderly patients using electrolyte therapy and antibiotics. Inactivated and live vaccines for prevention and control typhoid fever has been developed [63].

\section{Conclusions}

Infection with Salmonellae is of great zoonotic and public health importance in Egypt. So, collaboration between human and veterinary practitioners is very crucial to increase the awareness and education toward the disease importance especially among susceptible risky groups. Last but not least, there is an urgent need for strengthening environmental and behavioral intervention plans to reduce the burden of the disease.

\section{References}

1. Chaudhry R, Mahajan RK, Diwan A, Khan S, Singhal R, Chandel DS, Hans C (2003) Unusual presentation of enteric fever: three cases of splenic and liver abscesses due to Salmonella typhi and Salmonella paratyphi A. Trop Gastroenterol 24: 198-199.

2. Fabrega, A, Viola J (2013) Salmonella enterica serovar Typhimurium skills to succeed in the host: Virulence and regulation. Clin Microbiol Rev 26: 308341.https://doi.org/10.1128/CMR.00066-12

3. Ekdahl K, de Jong B, Wollin R, Andersson Y (2005) Travelassociated non-typhoidal salmonellosis: geographical and seasonal differences and serotype distribution. Clin Microbiol Infect 11: 138-144. doi: 10.1111/j.1469-0691.2004.01045.x

4. Wafaa AA, El-Shafii S, Hatem M (2012) A survey on Salmonella species isolated from chicken flocks in Egypt. Asian J Anim Vet Adv 7: 489-501. doi: 10.3923/ajava.2012.489.501

5. Gould LH, Walsh KA, Vieira AR, Herman K, Williams IT, Hall AJ, Cole D (2013) Centers for Disease Control and Prevention. Surveillance for foodborne disease outbreaksUnited States, 1998-2008. MMWR Surveill Summ 62: 1-34.

6. Center for Disease Control and Prevention (1996) Salmonella enteritidis infection and shell-eggs- United States. MMWR 39: 900-912.

7. Antunes P, Mourão J, Campos J, Peixe L (2016) Salmonellosis: the role of poultry meat. Clin Microbiol Infect 22: 110-121. doi: 10.1016/j.cmi.2015.12.004

8. Helmy YA, El-Adawy H, Abdelwhab EM (2017) A comprehensive review of common bacterial, parasitic and viral zoonoses at the human-animal interface in Egypt. Pathogens 6: 33. doi: $10.3390 /$ pathogens6030033

9. Cirillo VJ (2014) Arthur Conan Doyle (1859-1930): Physician during the typhoid epidemic in the Anglo-Boer War (18991902). J Med Biogr 22: 2-8. doi: 10.1177/0967772013493239

10. Crump JA, Youssef FG, Luby SP, Wasfy MO, Rangel JM, Taalat M, Oun SA, Mahoney FJ (2003) Estimating the incidence of typhoid fever and other febrile illnesses in developing countries. Emerg Infect Dis 9: 539-544. doi: 10.3201/eid0905.020428

11. Srikantiah P, Girgis FY, Luby SP, Jennings G, Wasfy MO, Crump JA, Hoekstra RM, Anwer M, Mahoney FJ (2006) Population-based surveillance of typhoid fever in Egypt. Am J Trop Med Hyg 74: 114-119. doi: 10.4269/ajtmh.2006.74.114

12. Eissa EA., EL-Sayed TI, Attia AA, Rashed ME, Refaat HM (2018) Proinflammatory cytokines in plasma of patients with 
typhoid fever and resistance to therapy. Egypt J Microbiol 53: 141-149.

13. Bashir S, Haque A, Ahmed N, Raza A, Haque A, Sarwar Y, Ali A, Bashir S, Mohsin M, Ahmed I, Ahmed J (2005) Significant incidence of typhoid in hepatitis C patients. Professional Med J 12: 287-294.

14. Hany MI, Elelaimy IA, El Shaer RE, Rabea RM (2018) Prevalence and evaluation of salmonellosis and brucellosis in chronic hepatitis $\mathrm{C}$ virus patients from Egypt. Int $\mathrm{J}$ Curr Adv Res 7: 2319-6505.

15. Mahmoud MS, Esmail MA, Khairy RMM, Mazhe OS (2015) Detection of multi-drug resistant non-typhoid Salmonella isolates in cases of gastroenteritis in Egypt. Microbiol Res J Int 6: 167-174. doi: 10.9734/BMRJ/2015/14322

16. Humphrey TJ (1999) Important and relevant attributes of the Salmonella organisms. Vet Sci Zootenica Int 8: 48-51.

17. El-Shaboury FA, Basha OA (2009) Epidemiological studies on salmonellosis in broiler chicken farms in Alexandria governorate. Assiut Vet Med J 55: 401-410.

18. Mohamed F, Mohamed M, Shata N, Manaa A (2009). Detection and identification of Salmonella isolated from chickens by PCR. Assiut Vet Med 55: 211-225.

19. Rabie NS, Khalifa NO, Radwan MEI, Afify JSA (2012) Epidemiological and molecular studies of Salmonella isolates from chicken, chicken meat and human in Toukh, Egypt. Global Vet 8: 128-132.

20. Ammar A, Ahmed A, Asawy A, Ibrahim A (2010) Bacteriological studies on Salmonella entertidis isolated from different sources in Dakhlia governorate. Assiut Vet Med J 56: $125-135$

21. Ammar A, Mohamed A, Abd El-Hamid M, El-Azzouny M (2016). Virulence genotypes of clinical Salmonella serovars from broilers in Egypt. J Infect Dev Ctries 10: 337-346. doi: $10.3855 /$ jidc. 7437

22. El-Sharkawy H, Tahoun A, El-Gohary AEA, El-Abasy M, ElKhayat F, Gillespie T, Kitade Y, Hafez HM, Neubauer H, ElAdawy H (2017) Epidemiological, molecular characterization and antibiotic resistance of Salmonella enterica serovars isolated from chicken farms in Egypt. Gut Pathog 9: 8. doi: 10.1186/s13099-017-0157-1

23. Shaltout FA, Nada SM, Fawzy WS (2019) Prevalence of Salmonella in some chicken meat products. Benha Vet Med J 36: 33-39. doi: 10.21608/bvmj.2019.12944.1012

24. Osman KM, Mehrez M, Erfan AM, Nayerah A (2013) Salmonella enterica isolated from pigeon (Columbalivia) in Egypt. Foodborne Pathog Dis 10: 481-483. doi: 10.1089/fpd.2012.1347

25. Osman KM, Marouf SH, Zolnikov TR, AlAtfeehy N (2014) Isolation and characterization of Salmonella enterica in dayold ducklings in Egypt. Pathog Glob Health 108: 37-48. doi: 10.1179/2047773213Y.0000000118

26. Tarabees R, Elsayed MSA, Shawish R, Basiouni S, Shehata AA (2017). Isolation and characterization of Salmonella Enteritidis and Salmonella Typhimurium from chicken meat in Egypt. J Infect Dev Ctries 11: 314-319. doi: 10.3855/jidc.8043

27. Abdel-Aziz N (2016) Detection of Salmonella species in chicken carcasses using genus specific primer belong to invA gene in Sohag city, Egypt. Vet World 9: 1125-1128. doi: 10.14202/vetworld.2016.1125-1128

28. Elkenany R, Elsayed MM, Zakaria AI, El-Sayed SA, Rizk MA (2019) Antimicrobial resistance profiles and virulence genotyping of Salmonella enterica serovars recovered from broiler chickens and chicken carcasses in Egypt. BMC Vet Res 15: 124. doi: 10.1186/s12917-019-1867-Z

29. Saad SM, Nada S, Abd El Sattar SS (2015) Incidence of Salmonella species in chicken cut-up carcasses and chicken products. Benha Vet Med J 29: 29-35. doi: 10.21608/bvmj.2015.31542

30. El-Tras WF, Tayel AA, Samir A (2010) Potential zoonotic pathways of Salmonella enteritidis in laying farms. Vector Borne Zoonotic Dis 10: 739-742. doi: 10.1089/vbz.2009.0080

31. El-Prince E, Hussein MF, Abd El-Rahman AM (2019). Incidence of Salmonella species in table eggs and some eggbased products. J Adv Vet Res 9: 1-7.

32. Gwida M, AlAshmawy M (2014) Culture versus PCR for Salmonella species identification in some dairy products and dairy handlers with special concern to its zoonotic importance. Vet Med Int 502370: 46. doi: 10.1155/2014/502370

33. Ahmed AM, Shimamoto T (2014) Isolation and molecular characterization of Salmonella enterica, Escherichia coli O157:H7 and Shigella spp. from meat and dairy products in Egypt. Int $\mathrm{J}$ Food Microbiol 168-169: 57-62. doi: 10.1016/j.ijfoodmicro.2013.10.014

34. Ahmed AM, Shimamoto T, Shimamoto T (2014) Characterization of integrons and resistance genes in multidrug-resistant Salmonella enterica isolated from meat and dairy products in Egypt. Int J Food Microbiol 189: 39-44. doi: 10.1016/j.ijfoodmicro.2014.07.031

35. Bakr W, ElSayed A, ElShamy H, Amine A (2013) Is it safe to eat raw sea food? Prevalence of Salmonella in some seafood products sold in Alexandria markets. J Egypt Public Health Assoc 88: 115-120. doi: 10.1097/01.EPX.0000433559.22563.47

36. Younis, EE, Ahmed AM, El-Khodery SA, Osman SA, ElNaker YF (2009). Molecular screening and risk factors of enterotoxigenic Escherichia coli and Salmonella spp. in diarrheic neonatal calves in Egypt. Res Vet Sci 87: 373-379. doi: 10.1016/j.rvsc.2009.04.006

37. Ghoneim NH, Abdel-Moein KA, Zaher H (2017). Camel as a transboundary vector for emerging exotic Salmonella serovars. Pathog Glob Health 111: 143-147. doi: 10.1080/20477724.2017.1309343

38. Kassem I, Helmy YA, Kashoma IP, Rajashekara G (2016). The emergence of antibiotic resistance on poultry farms. In Ricke S, editor. Achieving Sustainable Production of Poultry Meat: Safety, Quality and Sustainability, Volume 1. Cambridge: Burleigh Dodds Science Publishing. 67-80. doi: 10.19103/AS.2016.0010.05

39. Humphrey TJ (2000) Public health aspects of Salmonella infection. In Way $\mathrm{C}$ and Way A editors. Salmonella in domestic animals. Oxon, United Kingdom: CABI Publishing. 245-263. doi: 10.1079/9780851992617.0245

40. Fangtham M, Wilde H (2005) Emergence of Salmonella paratyphi A as a major cause of enteric fever: Need for early detection, preventive measures and effective vaccines. J Travel Med 15: 344-350. doi: 10.1111/j.1708-8305.2008.00237.x

41. Chen HM, Wang Y, Su LH, Chiu CH (2013) Nontyphoid Salmonella infection: microbiology, clinical features, and antimicrobial therapy. Pediatr Neonatol 54: 147-152. doi: 10.1016/j.pedneo.2013.01.010

42. Dougan G, Baker S (2014) Salmonella enterica serovar Typhi and the pathogenesis of typhoid fever. Annu Rev Microbiol 68: 317-336. doi: 10.1146/annurev-micro-091313-103739

43. Pandit A, Arjyal A, Paudyal B, Campbell JC, Day JN, Farrar JJ, Basnyat B (2008) A patient with paratyphoid A fever: an 
emerging problem in Asia and not always a benign disease. $\mathrm{J}$ Travel Med 15: 364-365. doi: 10.1111/j.17088305.2008.00238.x

44. Blaser MJ, Newman LS (1982) A review of human salmonellosis. I. Infective dose. Rev Infect Dis 4: 1096-1106. doi: 10.1093/clinids/4.6.1096

45. Singh S (2001) Symposium: typhoid fever pathogenesis and laboratory diagnosis. J Indian Acad Clin Med 2: 17-20.

46. Khan FY, Kamha AA, Alomary IY (2006) Fulminant hepatic failure caused by Salmonella paratyphi A Infection. World J Gastroenterol 12: 5253-5255.

47. Kumar S, Rizvi M, Berry N (2008) Rising prevalence of enteric fever due to multidrug-resistant Salmonella: an epidemiological study. J Med Microbiol 57: 1247-1250. doi: 10.1099/jmm.0.2008/001719-0

48. Khan FY, Al-Ani A, Ali HA (2009) Typhoid rhabdomyolysis with acute renal failure and acute pancreatitis: a case report and review of the literature. Int J Infect Dis 13: e282-e285. doi: 10.1016/j.ijid.2008.11.009

49. Abdel Ghani SM, Moland ES, Black JA, Hanson ND, Goering RV, Thomson KS, Amine MA, Saafan AE, Helal S, Gaafar M, Younan M (2010) First report of CTX-M-14 producing clinical isolates of Salmonella serovar Typhimurium from Egypt. J Infect Dev Ctries 4: 58-60. doi: 10.3855/jidc.386

50. Rowe B, Ward LR, Threlfall EJ (1997) Multidrug-resistant Salmonella Typhi: a worldwide epidemic. Clin Infect Dis 24 Suppl 1: 106-109. doi: 10.1093/clinids/24.Supplement 1.S106

51. European Food Safety Authority (2015) EU summary report on antimicrobial resistance in zoonotic and indicator bacteria from humans, animals and food in 2013. EFSA J 13: 4036. doi: 10.2903/j.efsa.2015.4036

52. Ahmed HA, El-Hofy FI, Shafik SM, Abdelrahman MA, Elsaid GA (2016) Characterization of virulence-associated genes, antimicrobial resistance genes, and class 1 integrons in Salmonella enterica serovar Typhimurium isolates from chicken meat and humans in Egypt. Foodborne Pathog Dis 13: 281-288. doi: 10.1089/fpd.2015.2097

53. Osman KM, Marouf SH, Alatfeehy N (2013) Antimicrobial resistance and virulence-associated genes of Salmonella enterica subsp. enterica serotypes Muenster, Florian, Omuna, and Noya strains isolated from clinically diarrheic humans in Egypt. Microb Drug Resist 19: 370-377. doi: 10.1089/mdr.2012.0151

54. Saleh FOI, Ahmed HA, Khairy RMM, Abdelwahab SF (2014) Increased quinolone resistance among typhoid Salmonella isolated from Egyptian patients. J Infect Dev Ctries 8: 661-665. doi: $10.3855 /$ jidc. 4111

55. Khairy RMM (2015) Anti-microbial resistance of non-typhoid Salmonella in Egypt. Fermentol Techno 4: 123.
56. Aouf A, Y Messai, Salama MS, Aboushady HM, El-Anany MG, Alouache S, Bakour R (2011) Resistance to $\beta$-lactams of human and veterinary Salmonella isolates in Egypt and Algeria. Afr J Microbiol Res 5: 802-808. doi: 10.5897/AJMR10.717

57. Wafaa AA, El-Shafii SSA, Hatem ME, Dawood RE (2012) A trial to prevent Salmonella Enteritidis infection in broiler chickens using autogenous bacterin compared with probiotic preparation. J Agri Sci 4: 91-108. doi: 10.5539/jas.v4n5p91

58. Mohammed NN, Sadek, MA, Abdel Aziz WR, Soliman EM, Zaki ESA, Ibrahim HM (2015) Efficacy of locally prepared Salmonella Kentucky vaccine in chicken. Benha Vet Med J 29: 153-160. doi: 10.21608/bvmj.2015.31687

59. Khafagy AA, Salama SS, Ibrahem RA (2018) Preparation and evaluation of local polyvalent inactivated Salmonella Enterica Serovar Enteritidis, Typhimurium and Kentucky vaccine for protection against salmonellosis in chickens in Egypt. SCVMJ XXIII: 95-111. doi: 10.21608/scvmj.2018.60771

60. El-Maghraby AS, Abdelaziz WR, Abd El-Moneam MM, Helal AM (2019) Efficacy of locally prepared inactivated combined vaccine of Salmonella enteritidis, Salmonella typhimurium, avian influenza (H9N2) and Newcastle disease viruses. Bioscience Res 16: 1668-1678.

61. Patrick ME, Adcock PM, Gomez TM, Altekruse SF, Holland BH, Tauxe RV, Swerdlow DL (2004) Salmonella Enteritidis infections, United States, 1985-1999. Emerg Infect Dis 10: 17. doi: 10.3201/eid1001.020572

62. Lohiniva AL, Saeed M, EL-Sayeed N, Talaat M (2008) Clean hands: Prevention of typhoid fever in rural communities in Egypt. Int'1. Int Q Community Health Educ 28: 215-227. doi: 10.2190/IQ.28.3.d

63. World Health Organization (2018) Use of typhoid fever vaccine. Weekly Epidemiological Monitor 11. Available: https://applications.emro.who.int/docs/epi/2018/Epi_Monitor _2018_11_21.pdf?ua=1\&ua=1 Accessed: 17 July 2020.

\section{Corresponding author}

Wafaa A Abd El-Ghany

Professor of Poultry Diseases, Poultry Diseases Department, Faculty of Veterinary Medicine, Cairo University, Giza, Giza Square, Egypt

Postal Code, 12211.

Tel: +02 01224407992,

Email:wafaa.ghany@yahoo.com

Conflict of interests: No conflict of interests is declared. 